\title{
THREE NEW CHORIPETALAE FROM NORTH AMERICA AND MEXICO.
}

Silene rectiramea. - Cespitose perennial, 2 to $3^{\mathrm{dm}}$ high: stems ser. eral from a multicipital caudex, covered at the base by the pale scarios: persistent scale-like ciliated bases of the earliest leaves, terete or elliptic in section, slightly striate in a dried state, pubescent and more or less viscid especially above, sometimes simple to the inflorescence, sometimes branched from every node; lower internodes relatively short, often curved, the middle and upper elongated, 6 to $8^{\mathrm{cm}}$ long, much exceeding the leaves, remarkably straight; branches solitary or 0pposite at the nodes, diverging from the stem at a uniform angle of about $45^{\circ}$; their internodes'also elongated and very straight: leaves of the stem about five pairs; the lower ones, like the radical, oblanceolate, 2.4 to $4^{\mathrm{em}}$ long, 4 to $7^{\mathrm{mm}}$ broad, the middle and upper lance-oblong to linear, all acute, I-nerved, obscurely pinnate-veined, minutely papillose and pulverulent-puberulent under a strong lens: bracts lance-lineart often purplish, 7 to $9^{\mathrm{mm}}$ long; bractlets similar, $2^{\mathrm{mm}}$ long: flowers terminal on the divergent branches of and open flat-topped cyme, in weaker stems reduced to a terminal and one or two short-pedicelec lateral ones; calyx cylindric in anthesis, white and papery but veined with light purple, $9^{\mathrm{mm}}$ long, Io-nerved; the nerves opposite the tet? branching freely, intermediate ones subsimple; teeth orbicular wit incurved margins : gynophore in anthesis 1.7 , in fruit $2.5^{\mathrm{mm}}$ ulate, subauriculate at the summit, 3-veined; blade short, 2 to 3 long, bifid a fourth of its length : stamens io, equal: carpels 3 ; cap sule ovoid, $7^{\mathrm{mm}}$ long, at maturity $\mathrm{I}$-celled to the very base: seeds red dish-brown, tubercles in few concentric series, those of the dorsal regit enlarged and forming a more or less definite crest.

Collected by Professor D. T. MacDougal about the Grand Cañon of th Colorado in Arizona, altitude $2150^{\mathrm{m}}, 28$ June, 1898 , no. $18 \mathrm{I}$. Type in beth
Gray.

This species stands near $S$. verecunda Watson, but differs in its elot gated very straight branches and delicate papery calyx, which, although $x^{2}$ rowly cylindric to obovoid, shows 110 indication of the tightening or constrit tion about the carpophore which is to be noticed in $S$. verecunda. Specimetis $S$. rectiramea were distributed in Mr. MacDougal's interesting Arizona but were determined only to the genus. Mr. A. A. Heller, who has ty charge of the identification of the sets, has courteously waived in favor author his right to characterize this species. 
Arabis Crandallii. - Cespitose perennial, $3^{\mathrm{dm}}$ high, pale green and hoary puberulent throughout, with minute stellate interplexed hairs: stems numerous (20 or more), slender, terete, from a loosely multicipital caudex : root single, vertical : radical leaves oblanceolatespatulate, 1.5 to $1.8^{\mathrm{cm}}$ long, 3 to $4^{\mathrm{mm}}$ broad, entire, acutish, cuneateattenuate at the base, concolorous, minutely stellate-tomentulose on both surfaces, I-nerved; the cauline (about 8 on each stem) similar but shorter and more oblong, sessile by a subamplexicaul base: pedicels ascending or appressed, 5 to $6^{\mathrm{nm}}$ long, slightly enlarged at the summit : sepals oblong, obtuse, stellate-puberulent, often purplish-tinged, $3^{\mathrm{mm}}$ long: petals obovate, cuneate, white, roseate-tinged, twice as long as the calyx: pods erect, slender, subtorulose in dried specimens, 2.5 to $4^{\mathrm{mm}}$ long, $\mathrm{I}^{\mathrm{mm}}$ broad, flattened; seeds (immature) uniseriate in each cell and nearly or quite as broad as the septum.

Collected by Professor C. S. Crandall at Cimmarron, Montrose co., Colorado, attitude $2100^{\mathrm{m}}$, I 8 May, 1898 , no. 6. Type in herb. Gray. In habit this species most nearly approaches the Canadian $A$. Macounii
Wats., from which, however, it is clearly distinguished by its fine stellate pubescence, shorter erect pods, and larger leaves. Mimosa acapulcensis (Subg. Eumimosa Ser. Sensitiva).- - Shrub I.5
to $3^{\mathrm{m}}$ high : branches terete, subflexuous, covered with a yellowish-gray striate cortex and armed with scattered, firm, grayish-brown, laterally 3 -foliompred, slightly recurved spines: leaves unijugate and pinnæ 3 -foliolate in the manner of $M$. sensitiva (a diminutive fourth leaflet occasionally present); leaflets glabrous, glaucous, coriaceous, oblong, entire, very oblique at the base, oblong, 3 to $10^{\mathrm{cm}}$ long, nearly half as broad; common petioles slender, wiry, 3 to $8^{\mathrm{cm}}$ long; secondary rhachises 2 to $3.5^{\mathrm{cm}}$ long: peduncles slender, ascending, fascicled by 3 's, 4 's, and 5 's
along the terminal portion of the branch, and forming a loose, elon-
gated, relatively gated, relatively narrow inflorescence, leafy towards the base: heads
globose, $1.5^{\mathrm{cm}}$ in perfect and $1.5^{\mathrm{cm}}$ in diameter (incl. the long stamens), roseate; flowers date-denticulate: toothed ; teeth : corolla $2.7^{\mathrm{mm}}$ long, glabrous, 3-4-nerved and $3^{-4}$ $4^{\infty}$ long, glabrous and the the a third as long as the tube 2.5 to long-stiped, torose, acumolly unarmed both as to valves and replum, at maturity; valves acuminate at the tip, 3-4-jointed, Indian-brown 
Common on hills near Acapulco, Mexico, where collected by Dr. Edwart Palmer between October I 894 and March I 895 , no. 296.

I am indebted to Dr. Rose for calling my attention to this species, Dr. Palmer's specimen having been undistributed in the Gray Herbarium at the time of my recent revision of the genus. Types in herb. Gray and herb. U.S National Museum. - B. L. RoBinson.

\section{THE PROBABLE CAUSES OF THE POISONOUS EFFECTS} OF THE DARNEL (LOLIUM TEMULENTUM L.).

THE presence of a poisonous principle in the darnel has been well known since the earliest investigations of the subject, and recent experiments confirm this fact. According to Hofmeister, ${ }^{\mathrm{T}}$ the darnet contains two active principles: temulin, obtained by this author 2 chloroplatinate, which acts upon the nervous system; and the other determined by the oily substances and fatty acids which are contained in the seed in large proportion, which attacks the alimentary canal.

In the course of our researches upon the seed integuments and the pericarp of grasses, we have had occasion to note the practically constant presence in the seeds of the darnel of a fungus to which it seemed reasonable to us to assign the poisonous effects. This fungus, which is always present in the form of mycelial filaments, appears at an early stage in the interior of the ovary. In the first stages of its develop ment it invades the entire nucellus. At the time that the externa integument of the ovule disappears, the nucellus itself is almost entirely resorbed, with the exception of two or three of the outermost lavers which, obliterated in the maturing of the grain, constitute the hraline layer. Crowded out by the development of endosperm after fertilitation, the mycelium becomes restricted between this hyaline laver and the outermost endosperm. It is in this zone that we have observed it in the mature seed. After the removal of the diverse coatings of the fruit, the byphæ which constitute this fungus zone appear as septat filaments, generally very long, more or less branched and interworet with one another. We have found this disposition of the fungus if material from Bolivia, Brazil, Chili, Abyssinia, Persia, Syria, Spain Portugal, Sweden, Germany, and many localities in France. In fort seeds of most diverse origin the mycelial zone was lacking from bor

${ }^{1}$ Archiv. f. exp. Path. u. Pharm. 30:-. 1892. 


\section{$2 \mathrm{BHL}$ Biodiversity Heritage Library}

Robinson, B L. 1899. "Three New Choripetalae from North America and Mexico." Botanical gazette 28(2), 134-136. https://doi.org/10.1086/327884.

View This Item Online: https://www.biodiversitylibrary.org/item/94876

DOI: https://doi.org/10.1086/327884

Permalink: https://www.biodiversitylibrary.org/partpdf/222991

\section{Holding Institution}

Missouri Botanical Garden, Peter H. Raven Library

\section{Sponsored by}

Missouri Botanical Garden

\section{Copyright \& Reuse}

Copyright Status: Public domain. The BHL considers that this work is no longer under copyright protection.

This document was created from content at the Biodiversity Heritage Library, the world's largest open access digital library for biodiversity literature and archives. Visit BHL at https://www.biodiversitylibrary.org. 